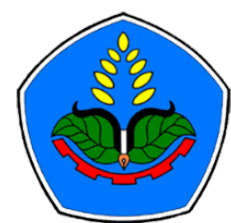

AGROPROSS

National Conference

Proceedings of Agriculture
Proceedings:

Peningkatan Produktivitas Pertanian Era Society 5.0 Pasca Pandemi

Tempat : Politeknik Negeri Jember

Tanggal : 22 Juli 2021

Publisher :

Agropross, National Conference Proceedings of Agriculture

ISBN : 978-623-94036-6-9

DOI : 10.25047 /agropross.2021.202

\title{
Aplikasi Berbagai Jenis Media dan ZPT Terhadap Aklimatisasi Anggrek Vanda (Vanda sp.)
}

\author{
Author(s): Annisa Firdausy Nuzullah ${ }^{(1)}$; Refa Firgiyanto ${ }^{(2)^{*}}$
}

(1) Mahasiswa Program Studi Produksi Tanaman Hortikultura, Jurusan Produksi Pertanian, Politeknik Negeri Jember

(2) Dosen Program Studi Produksi Tanaman Hortikultura, Jurusan Produksi Pertanian, Politeknik Negeri Jember

* Corresponding author: refa_firgiyanto@polije.ac.id

\section{ABSTRACT}

Orchids can be cultivated vegetatively or generatively. Tissue culture technique is one of the generative propagation. Plants from tissue culture are plants that are still susceptible to theenvironment in-vivo. Improper adjustment of plants will reduce the success rate of the acclimatization process. The use of media is one of the success factors in the acclimatization stage. The ZPT application aims to support the success rate of acclimatization and increase the slow growth of vanda orchid plants. The purpose of this study was to determine the best results of the application of planting media, the application of ZPT and the interaction on the acclimatization of orchids. The method used was factorial Randomized Block Design (RAK), consisting of two factors. Each factor consisted of 3 levels of treatment with 3 replications, each replication consisted of 3 plants, resulting in 9 combinations of treatment with growing media and ZPT, namely, M1Z1: (cocopeat media + shallots), M1Z2: (cocopeat media + bean sprouts), M1Z3: (cocopeat media + bean sprouts), M1Z3: (cocopeat media + bean sprouts). cocopeat+coconut water), M2Z1 (fern media + red onion), M2Z2 (fern media + bean sprouts), M2Z3 (fern media + coconut water), M3Z1 (moss media + shallots), M3Z2 (moss media + bean sprouts), M3Z3 (moss media + water coconut). The DMRT 5\% test results showed that the application of cocopeat (M1) media showed the best results on the percentage of live parameters, increase in plant height at 3 weeks, wet weight, dry weight, moisture content and root volume. The single factor of onion plant growth factor (Z1) showed significantly different results only on the wet weight parameter. Cocopeat media and shallot PGR (M1Z1) showed a significant effect on the parameter addition of 9 MST stem diameter and wet weight.

\section{Keywords:}

acclimatization;

vanda orchid;

shallot;

cocopeat.

\section{Kata Kunci: ABSTRAK}

aklimatisasi; anggrek vanda; bawang merah; cocopeat..
Anggrek dapat dibudidayakan secara vegetatif maupun generatif. Teknik kultur jaringan merupakan salah satu perbanyakan secara generatif. Tanaman hasil kultur jaringan merupakan tanaman yang masih rentan terhadap lingkungan in-vivo. Penyesuaian tanaman yang tidak tepat akan menurunkan tingkat keberhasilan proses aklimatisasi. Penggunaan media merupakan salah satu faktor keberhasilan tahap aklimatisasi. Aplikasi ZPT bertujuan untuk mendukung tingkat keberhasilan aklimatisasi dan meningkatkan pertumbuhan tanaman anggrek vanda yang lambat. Tujuan penelitian ini ialah untuk mengetahui hasil terbaik pengaplikasian media tanam, pengaplikasian ZPT serta interaksi pada aklimatisasi anggrek. Metode yang digunakan adalah Rancangan Acak Kelompok (RAK) faktorial, terdiri dari dua faktor. Tiap faktok terdiri dari 3 taraf perlakuan dengan 3 ulangan, tiap ulangan terdiri dari 3 tanaman, menghasilkan 9 kombinasi perlakuam media tanam dan ZPT yaitu, M1Z1: (media cocopeat+ bawang merah), M1Z2: (media cocopeat+tauge), M1Z3: (media cocopeat+air kelapa), M2Z1 (media pakis + bawang mera), M2Z2 (media pakis + tauge), M2Z3 (media pakis + air kelapa), M3Z1 (media moss + bawang merah), M3Z2 (media moss+ tauge), M3Z3 (media moss+ air kelapa). Hasil uji DMRT $5 \%$ menunjukkan bahwa pengaplikasian jenis media cocopeat (M1) menunjukkan hasil terbaik pada parameter presentase hidup, penambahan tinggi tanaman minggu ke-3, bobot basah, bobot kering, kadar air dan volume akar. Faktor tunggal jenis ZPT bawang merah (Z1) menunjukkan hasil berbeda nyata hanya pada parameter bobot basah. Media cocopeat dan ZPT bawang merah (M1Z1) menunjukkan hasil berpengaruh nyata pada parameter penambahan diameter batang 9 MST dan bobot basah. 


\section{PENDAHULUAN}

Anggrek merupakan tanaman hias bunga endemik yang menyebar luas di seluruh Indonesia. Spesies anggrek yang menyebar di seluruh Indonesia mencapai sekitar 5000 spesies. Anggrek adalah tanaman benalu yang memiliki nilai estetika yang tinggi sehingga memiliki nilai ekonomis yang tinggi. Anggrek sudah dikenal sejak 200 tahun lalu, sejak 50 tahun terakhir mulai dibudidayakan secara luas di Indonesia. Salah satu varietas anggrek yang mulai dibudidayakan yaitu anggrek Vanda. Menurut data Statistika Tanaman Hias (2018) produksi anggrek potong di Jawa Timur sudah meningkat, namun jika dibandingkan dengan tanaman lain masih rendah. Produksi anggrek keseluruhan di Indonesia pada tahun 2018 mencapai 24,717,840 tangkai sedangkan tanaman sedap malam 116,909,674 tangkai tanaman mawar 202,065,050 tangkai dan tanaman krisan 488,176,610 tangkai. Produksi dan luas panen anggrek jika dilihat data keseluruhan di Indonesia anggrek potong memiliki angka produksi $24,717,840$ pada tahun 2018 dengan luas produksi 176,77 ha dan $20,045,577$ di tahun 2017 dengan luas panen 172,2 ha sehingga memiliki perkembangan growth dari tahun 2017 ke 2018 sebesar 18,9\%.

Anggrek dapat dibudidayakan secara vegetatif maupun generatif. Perbanyakan secara vegetatif dapat dilakukan dengan perbanyakan melalui batang. Perbanyakan secara generatif dilakukan melalui buah anggrek, namun perbanyakan generative tidak bisa dilakukan langsung, karena dalam biji anggrek tidak mempunyai endosperm atau cadangan makanan sehingga biji tidak dapat tumbuh. Salah satu masalah anggrek vanda ialah pada teknologi yang digunakan untuk produksi masih sederhana, akibatnya kualitas dan produktivitas bunga masih rendah sehingga belum siap bersaing di pasaran internasional.

Perbanyakan generatif dapat dilakukan secara in-vitro, dalam teknik kultur jaringan tanaman mendapat suplai nutrisi dari media kultur yang diharapkan mampu sebagai pengganti endosperm tanaman sehingga tanaman dapat tumbuh secara optimal. Perbanyakan vegetatif tanaman dapat menghasilkan anakan 3-5 per tanaman, namun jika perbanyakan anggrek secara generatif melalui kultur jaringan dapat diperoleh anakan sekitar 30 anakan per botol. Anggrek yang telah ditanam secara in-vitro selama \pm 9 bulan kemudian dipindah tanam secara in-vivo atau di lapang. Pemindahan tanaman disebut sebagai proses aklimatisasi, aklimatisasi merupakan kelanjutan dari teknik perbanyakan in-vitro.

Aklimatisasi adalah penyapihan tanaman dari kondisi in-vitro untuk tumbuh dan berkembang pada kondisi invivo di lapang atau rumah kaca yang menunjukkan adanya campur tangan manusia dalam mengarahkan proses penyesuaian pada tahap akhir mikropropagasi (Zulkarnain, 2011). Maka dari itu tidak sedikit pada proses aklimatisasi terjadi penurunan persentase hidup tanaman yang dikarenakan tidak dapat beradaptasi dengan lingkungan lapang. Faktor yang mempengaruhi hal tersebut bisa dari lingkungan yang terlalu ekstrim, penggunaan media yang kurang baik, atau rentannya tanaman terhadap penyakit maupun jamur. Faktor yang mempengaruhi tahap aklimatisasi ialah suhu udara, kelembaban udara dan intensitas cahaya (Zulkarnain, 2011).

Pemakaian media tumbuh yang digunakan sebaiknya yang tidak lekas melapuk, tidak menjadi sumber penyakit, mampu mengikat air dan zat-zat hara secara baik, mudah didapat dalam jumlah yang diinginkan, murah, dan ramah lingkungan. Media yang biasanya di gunakan dalam budidaya anggrek yaitu: pakis, arang, moss, sabut kelapa, pecahan 
batu bata atau genteng, serbuk gergaji.

Penggunaan media moss, pakis dan kombinasi cocopeat + arang kayu memiliki pengaruh yang baik terhadap pertumbuhan anggrek hitam berdasarkan parameter tinggi tanaman, jumlah daun, warna daun, dan persentase hidup. Persentase hidup tertinggi diperoleh perlakuan kombinasi arang dan serabut kelapa. Penggunaan teknik compot atau single pot tidak menunjukkan perbedaan yang signifikan (Adi et al. 2014). Menurut Sucipto et al. (2019) penggunaan media terbaik pada perlakuan kombinasi media sabut kelapa + ampas tebu untuk Dendrobium sylvanum Rchb. f. secara optimal. Berdasar kajian diatas digunakan acuan penulis memilih penggunaan media pakis, cocopeat dan moss yang diharapkan meningkatkan pertumbuhan anggrek serta mengetahui apakah penggunaan cocopeat tanpa kombinasi apapun akan menunjukkan hasil terbaik pada anggrek vanda seperti pada anggrek hitam dan dendrobium.

Pertumbuhan anggrek relatif lama, butuh waktu cukup lama untuk mendapatkan tanaman anggrek dewasa. Proses aklimatisasi biasanya memakan waktu 3-4 bulan. Planlet hasil kultur invitro memiliki perakaran yang lemah sehingga sangat rentan dan tidak berfungsi dalam keadaan in-vivo. Akar in-vitro akan diganti dengan akar baru. Pertumbuhan akar yang lambat akan mempengaruhi pendistribusian air dan hara yang akan menghambat pertumbuhan anggrek. Pertumbuhan anggrek dapat dibantu dengan penambahan ZPT misalnya hormon auksin dan sitokinin.

Menurut Saputri et al. (2015) penambahan ekstrak tauge konsentrasi $7,5 \%$ dan $5 \%$ pada anggrek hitam in-vitro menunjukan hasil beda nyata dengan perlakuan lain namun berbeda nyata pada parameter jumlah tunas anggrek dan jumlah daun. Berdasar kajian tersebut penulis ingin menganalisis mengaplikasikan beberapa ZPT yang diharapkan dapat meningkatkan pertumbuhan tanaman anggrek diantaranya yaitu air kelapa, tauge, dan bawang merah. Pemilihan ZPT dipilih karena lebih mudah mencari bahan, ZPT tersebut merupakan ZPT dengan kandungan hormon alami dan nutrisi pendukung lainnya. Tauge sebagai auksin, bawang merah sebagai auksin, dan air kelapa sebagai sitokinin. Berdasar kajian tersebut penulis ingin mengetahui dan menganalisis apakah dengan pemberian yang sama pada setiap ZPT yang berbeda memperoleh hasil yang sama serta kombinasi media dan ZPT mana yang menunjukkan hasil terbaik. Adapun tujuan dari penelitian ini adalah mengetahui hasil terbaik pengaplikasian media tanam aklimatisasi anggrek, mengetahui hasil terbaik pengaplikasian ZPT pada aklimatisasi anggrek DAN mengetahui interaksi terbaik pengaplikasian media tanam aklimatisasi dan penambahan ZPT

\section{BAHAN DAN METODE}

Penelitian ini dilaksanakan selama 4 bulan dari bulan Juli hingga November 2020 di halaman atap rumah desa Maor, Kembangbahu, Lamongan dengan ketinggian tempat $\pm 5,17$ mdpl. Penelitian ini menggunakan anggrek vanda pak chong syam (hybrid). Penelitian ini menggunakan dua faktor, yang pertama media bahan tanam (M) terdiri dari (cocopeat, pakis, moss) dan faktor yang kedua ZPT alami (Z) terdiri dari (bawang merah, tauge, air kelapa). Metode penelitian menggunakan Rancangan Acak Kelompok faktorial (RAK) dengan dua faktor, terdiri dari 9 perlakuan dan 3 ulangan. Masing-masing ulangan terdiri dari 3 pot. Total tanaman ialah 81 tanaman. Variabel pengamatan Persentase hidup (\%), Penambahan tinggi tanaman $(\mathrm{mm})$, penambahan jumlah daun (helai), penambahan diameter batang $(\mathrm{mm})$, bobot basah (gr), panjang akar $(\mathrm{cm})$, volume 
akar (ml), bobot kering (gr), kadar air $(\mathrm{ml})$.

\section{HASIL DAN PEMBAHASAN}

Pertumbuhan dan perkembangan tanaman anggrek vanda bergantung pada perlakuan media tanam dan jenis media yang diaplikasikan. Respon tanaman pada pengaplikasian jenis media, jenis ZPT maupun interaksi media dan ZPT terhadap keberhasilan aklimatisasi serta pertumbuhan dapat dilihat pada analisis uji lanjut DMRT 5\%. Hasil analisis ragam faktor tunggal jenis media menunjukkan hasil berbeda sangat nyata pada parameter persentase hidup, parameter bobot basah dan kadar air. Parameter yang menunjukkan berbeda nyata pada penambahan tinggi tanaman pada minggu ke-3 dan bobot kering. Hasil analisis ragam faktor tunggal jenis ZPT menunjukkan hasil berbeda nyata pada parameter bobot basah. Interaksi dua faktor menunjukkan berbeda sangat nyata pada penambahan diameter batang minggu ke-9 dan berbeda nyata di bobot basah (Tabel 1).

Tabel 1 Rekapitulasi hasil sidik ragam terhadap parameter pengamatan

\begin{tabular}{|c|c|c|c|c|}
\hline \multirow{2}{*}{ No } & \multirow{2}{*}{ Variabel yang diamati } & \multicolumn{3}{|c|}{ Sumber keragaman } \\
\hline & & $\mathrm{M}$ & Z & $\mathrm{MZ}$ \\
\hline 1 & Persentase hidup (\%) & $* *$ & tn & tn \\
\hline 2 & Penambahan tinggi tanaman 3 MST (mm) & $*$ & tn & tn \\
\hline 3 & Penambahan tinggi tanaman 9 MST (mm) & tn & tn & tn \\
\hline 4 & Penambahan tinggi tanaman 15 MST (mm) & tn & tn & tn \\
\hline 5 & Penambahan jumlah daun 3 MST (helai) & tn & tn & $\operatorname{tn}$ \\
\hline 6 & Penambahan jumlah daun 9 MST (helai) & tn & tn & tn \\
\hline 7 & Penambahan jumlah daun 15 MST (helai) & tn & tn & tn \\
\hline 8 & Penambahan diameter batang 3 MST (mm) & tn & tn & tn \\
\hline 9 & Penambahan diameter batang 9 MST (mm) & $\operatorname{tn}$ & $\operatorname{tn}$ & $* *$ \\
\hline 10 & Penambahan diameter batang $15 \mathrm{MST}(\mathrm{mm})$ & tn & tn & tn \\
\hline 11 & Bobot basah (gr) & $* *$ & $*$ & $*$ \\
\hline 12 & Bobot kering (gr) & $*$ & tn & $\operatorname{tn}$ \\
\hline 13 & Kadar air (ml) & $* *$ & tn & $\operatorname{tn}$ \\
\hline 14 & Panjang akar (cm) & tn & tn & tn \\
\hline 15 & Volume akar (ml) & $* *$ & tn & $\operatorname{tn}$ \\
\hline
\end{tabular}

Keterangan : $\mathrm{M}=$ Jenis Media, $\mathrm{Z}=$ Jenis $\mathrm{ZPT}, \mathrm{MZ}=$ Interaksi antara pengaplikasian jenis media dan jenis $\mathrm{ZPT}, \mathrm{tn}=$ tidak nyata, ${ }^{*}=$ berbeda nyata, ${ }^{* *}=$ berbeda sangat nyata. Uji lanjut berdasarkan DMRT $5 \%$ dan $1 \%$. 
Tabel 2 Hasil DMRT pengaruh faktor aplikasi jenis media terhadap aplikasi jenis ZPT variabel pertumbuhan tanaman.

\begin{tabular}{|c|c|c|c|c|c|c|c|c|c|c|}
\hline \multirow{3}{*}{ Data Perlakuan } & \multirow[b]{3}{*}{$\mathrm{PH}(\%)$} & \multicolumn{9}{|c|}{ Variabel Pertumbuhan } \\
\hline & & \multicolumn{3}{|c|}{ PTT $(\mathrm{mm})$} & \multicolumn{3}{|c|}{ PJD (helai) } & \multicolumn{3}{|c|}{ PDB (mm) } \\
\hline & & $\begin{array}{c}3 \\
\text { MST }\end{array}$ & $\begin{array}{c}9 \\
\text { MST }\end{array}$ & $\begin{array}{c}15 \\
\text { MST }\end{array}$ & $\begin{array}{c}3 \\
\text { MST }\end{array}$ & $\begin{array}{c}9 \\
\text { MST }\end{array}$ & $\begin{array}{c}15 \\
\text { MST }\end{array}$ & $\begin{array}{c}3 \\
\text { MST }\end{array}$ & $\begin{array}{c}9 \\
\text { MST }\end{array}$ & $\begin{array}{c}15 \\
\text { MST }\end{array}$ \\
\hline Aplikasi jenis media & & & & & & & & & & \\
\hline M1 (cocopeat) & $92.59 \mathrm{a}$ & $1.893 \mathrm{ab}$ & 0.414 & 0.856 & 0.222 & 0.037 & 0.111 & 0.001 & 0.005 & 0.002 \\
\hline M2 (cacahan pakis) & $33.33 \mathrm{~b}$ & $2.151 \mathrm{a}$ & 0.778 & 0.111 & 0.185 & 0.074 & 0.000 & 0.002 & 0.003 & 0.003 \\
\hline M3 (moss) & $44.44 \mathrm{~b}$ & $1.340 \mathrm{~b}$ & 0.222 & 0.444 & 0.148 & 0.000 & 0.000 & 0.001 & 0.001 & 0.001 \\
\hline F hitung $M$ & $\begin{array}{c}11.20 \\
* *\end{array}$ & $\begin{array}{c}4.20 \\
*\end{array}$ & 2.49 & 1.96 & 0.44 & 1.07 & 1.99 & 0.61 & 2.88 & 0.81 \\
\hline Aplikasi jenis ZPT & & & & & & & & & & \\
\hline Z1 (bawang merah) & 59.26 & 1.741 & 0.289 & 0.478 & 0.148 & 0.093 & 0.037 & 0.002 & 0.004 & 0.003 \\
\hline $\mathrm{Z} 2$ (taoge) & 55.56 & 1.973 & 0.714 & 0.067 & 0.296 & 0.019 & 0.000 & 0.002 & 0.002 & 0.003 \\
\hline Z3 (air kelapa) & 55.56 & 1.670 & 0.411 & 0.867 & 0.111 & 0.000 & 0.074 & 0.001 & 0.003 & 0.001 \\
\hline F hitung $Z$ & 0.05 & 0.62 & 1.50 & 2.25 & 3.11 & 1.87 & 0.67 & 0.25 & 0.47 & 0.37 \\
\hline
\end{tabular}

Keterangan : PH : Persentase Hidup (\%), PTT : Penambahan Tinggi Tanaman (mm), PJD : Penambahan Jumlah Daun (helai), PDB = Penambahan Diameter Batang. Angka yang diikuti huruf yang sama pada kolom yang sama tidak berbeda nyata pada DMRT 5\% dan (**) menunjukkan berbeda sangat nyata dan $(*)$ menunjukkan berbeda nyata pada kolom yang sama pada DMRT 5\%.

Tabel 3 Hasil DMRT pengaruh faktor aplikasi jenis media terhadap aplikasi jenis ZPT variabel pertumbuhan (Lanjutan)

\begin{tabular}{lccccc}
\hline \multirow{2}{*}{ Data Perlakuan } & \multicolumn{5}{c}{ Variabel Pertumbuhan } \\
\cline { 2 - 6 } & BB $(\mathrm{gr})$ & $\mathrm{BK}(\mathrm{gr})$ & KA $(\%)$ & PA $(\mathrm{cm})$ & VA (ml) \\
\hline Aplikasi jenis media & & & & & \\
M1 (cocopeat) & $0.822 \mathrm{a}$ & $0.156 \mathrm{a}$ & $79.83 \mathrm{a}$ & 3.622 & $1.444 \mathrm{a}$ \\
M2 (cacahan pakis) & $0.333 \mathrm{~b}$ & $0.100 \mathrm{~b}$ & $69.44 \mathrm{~b}$ & 2.900 & $0.611 \mathrm{~b}$ \\
M3 (moss) & $0.344 \mathrm{~b}$ & $0.111 \mathrm{ab}$ & $61.67 \mathrm{~b}$ & 2.811 & $0.667 \mathrm{~b}$ \\
\hline F hitung M & 17.96 & 4.00 & 10.15 & 1.29 & 16.23 \\
& $* *$ & $*$ & $* *$ & & $* *$ \\
\hline Aplikasi jenis ZPT & & & & & \\
Z1 (bawang merah) & $0.644 \mathrm{a}$ & 0.144 & 72.53 & 3.456 & 0.944 \\
Z2 (tauge) & $0.522 \mathrm{ab}$ & 0.122 & 70.26 & 2.922 & 0.944 \\
Z3 (air kelapa) & $0.333 \mathrm{~b}$ & 0.100 & 68.15 & 2.956 & 0.833 \\
\hline \multicolumn{1}{c}{ F hitung Z } & 5.67 & 2.29 & 0.59 & 0.58 & 0.31 \\
\cline { 2 - 6 } & $*$ & & & & \\
\hline
\end{tabular}

Keterangan: BB = Bobot Basah (gr), BK = Bobot Kering (gr), KA = Kadar Air (ml), PA = Panjang Akar (cm), $\mathrm{VA}=$ Volume Akar (ml). Angka yang diikuti huruf yang sama pada kolom yang sama tidak berbeda nyata pada DMRT $5 \%$ dan (**) menunjukkan berbeda sangat nyata dan $(*)$ menunjukkan berbeda nyata pada kolom yang sama pada DMRT 5\%.

Hasil uji lanjut DMRT faktor tunggal jenis media di parameter persentase hidup mendapatkan nilai $\mathrm{F}$ hitung 11.20 menunjukkan hasil berbeda sangat nyata, hasil terbaik pada perlakuan
M1. Media cocopeat menunjukkan hasil lebih tinggi $64 \%$ jika dibandingkan dengan perlakuan media cacahan pakis, dapat dibaca pada gambar 1 . 


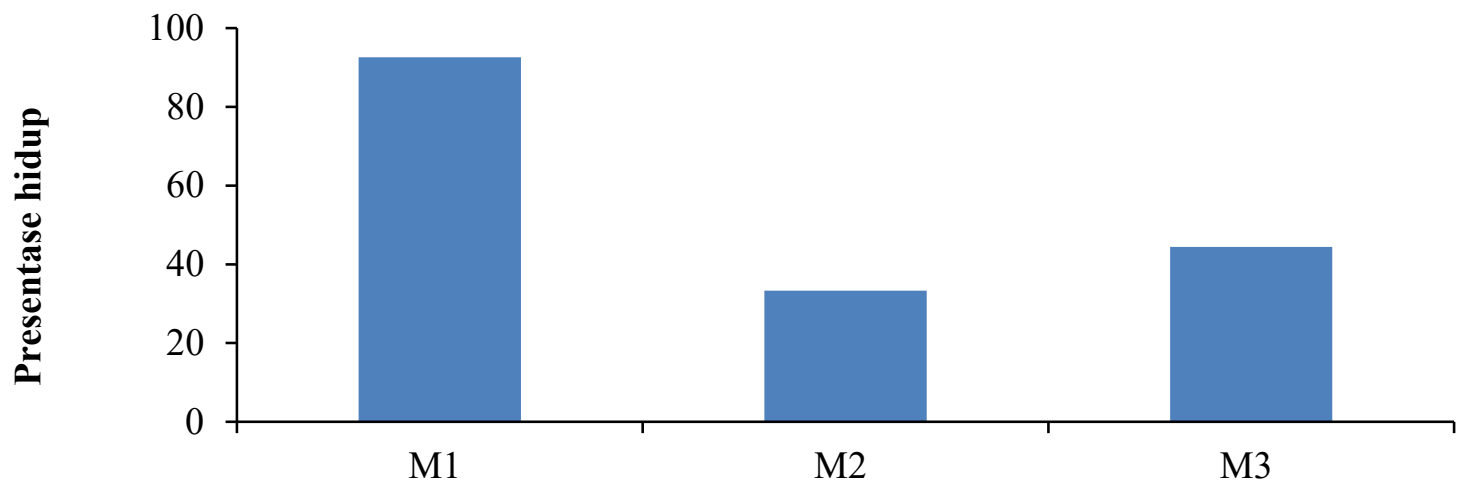

Gambar 1 Grafik Persentase Hidup Faktor Tunggal Media

Parameter penambahan tinggi tanaman 3 MST menunjukkan hasil terbaik M2 namun tidak berbeda nyata dengan M1 menunjukkan hasil berbeda nyata dengan nilai $\mathrm{F}$ hitung 4.20. Media cacahan pakis lebih tinggi $37.7 \%$ dibanding dengan media moss, namun lebih tinggi hanya $12 \%$ jika dibanding dengan perlakuan media cocopeat karena masih memiliki notasi yang sama. Parameter bobot basah mendapatkan nilai F hitung 17.96 menunjukkan hasil berbeda sangat nyata, hasil terbaik pada perlakuan M1. Perlakuan media cocopeat memiliki nilai lebih tinggi 59,5\% dibanding dengan perlakuan media cacahan pakis, dapat dibaca pada gambar 2 .

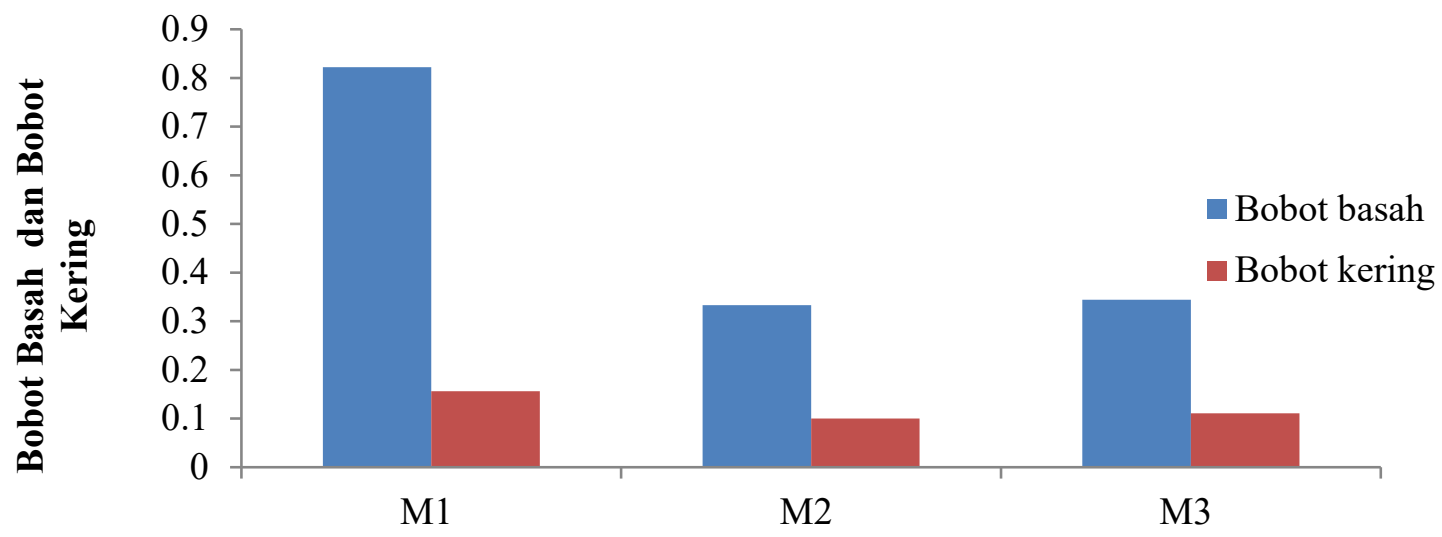

Gambar 2 Grafik Bobot Basah Dan Bobot Kering Faktor Tunggal Media

Parameter bobot kering mendapatkan nilai $\mathrm{F}$ hitung 4,0 menunjukkan hasil berbeda nyata, hasil terbaik menunjukkan pada parameter M1 namun tidak berbeda nyata dengan perlakuan M3. Perlakuan cocopeat memiliki nilai lebih tinggi $35,9 \%$ dari perlakuan media cacahan pakis. Parameter bobot basah dan bobot kering memiliki keselarasan, yaitu dengan hasil terbaik oleh perlakuan M1.

Parameter kadar air mendapatan nilai $\mathrm{F}$ hitung 10.15 menunjukkan hasil berbeda sangat nyata, hasil terbaik diperlakukan M1. Perlakuan media cocopeat lebih tinggi $22.7 \%$ dari perlakuan media moss, dapat dibaca pada gambar 3. 


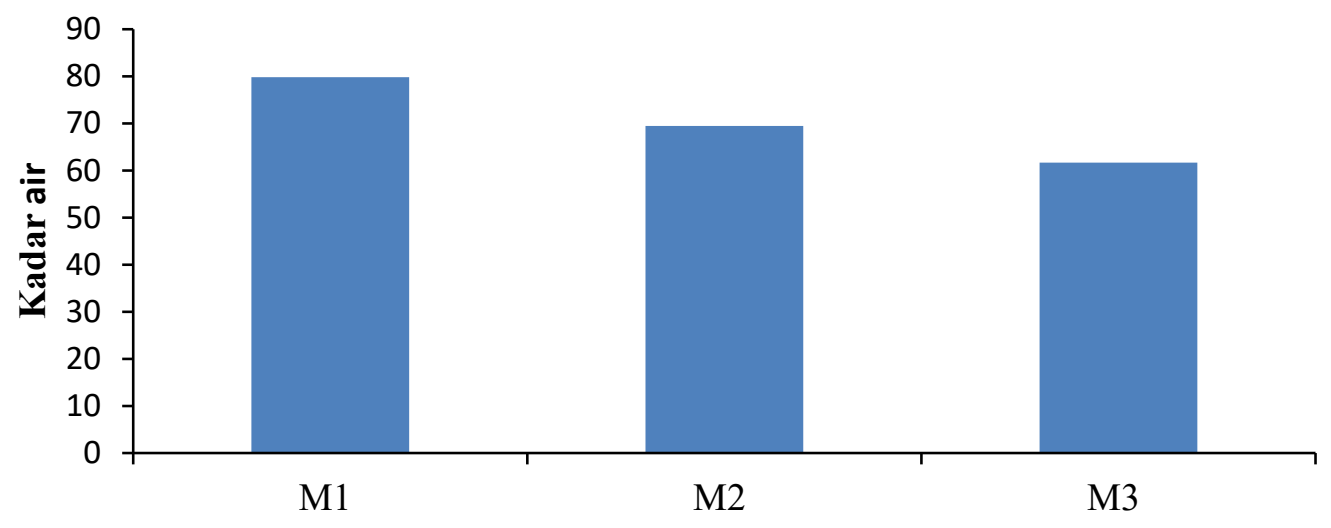

Gambar 3 Grafik Kadar Air Faktor Tunggal Media

Parameter volume akar mendapat nilai $\mathrm{F}$ hitung 16.23 yang menunjukkan bahwa perlakuan M1 menunjukkan hasil berbeda sangat nyata. Tingkat keporusan tanah juga dapat dilihat dari parameter volume akar. Perlakuan cocopeat lebih tinggi 57,69\% dari perlakuan pakis, dapat dilihat pada gambar 4 .

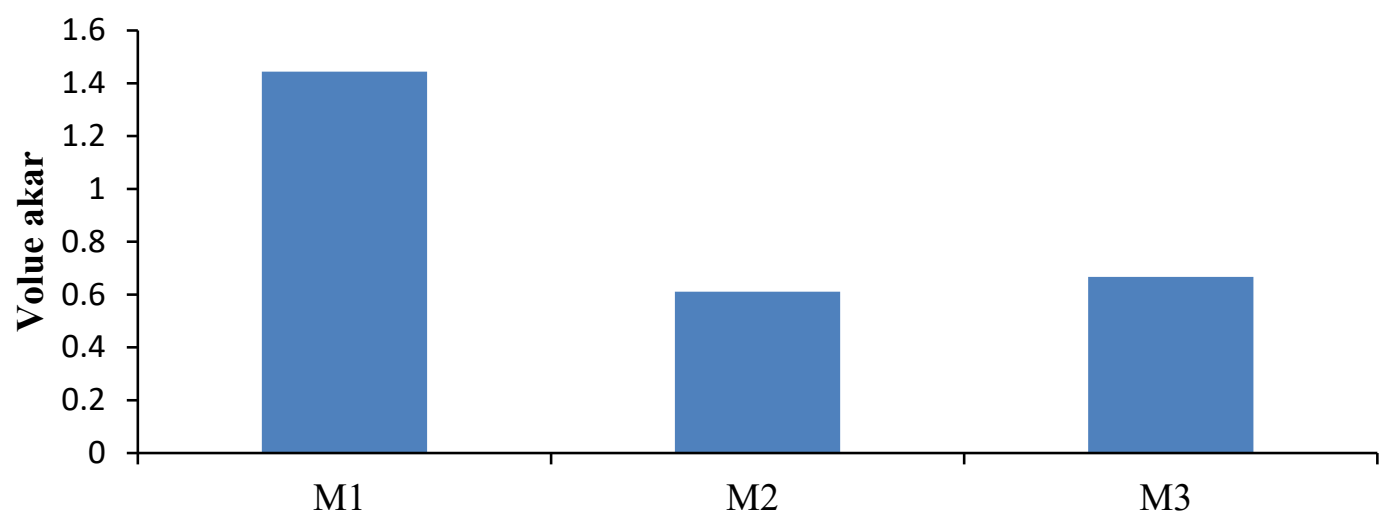

Gambar 4 Grafik Volume Akar Faktor Tunggal Media

Tingkat keporusan tanah dapat dinilai dari parameter volume akar yang menunjukkan bahwa cocopeat adalah media yang memiliki keporusan terbaik, sehingga tidak menghambat perakaran, sama halnya parameter panjang akar yng menunjukkan bahwa cocopeat mendapat nilai terbaik, meskipun mendapat hasil tidak berbeda nyata atau sama baik, namun media cocopeat masih memiliki nilai tertinggi yang dapat dilihat pada gambar 5 . 


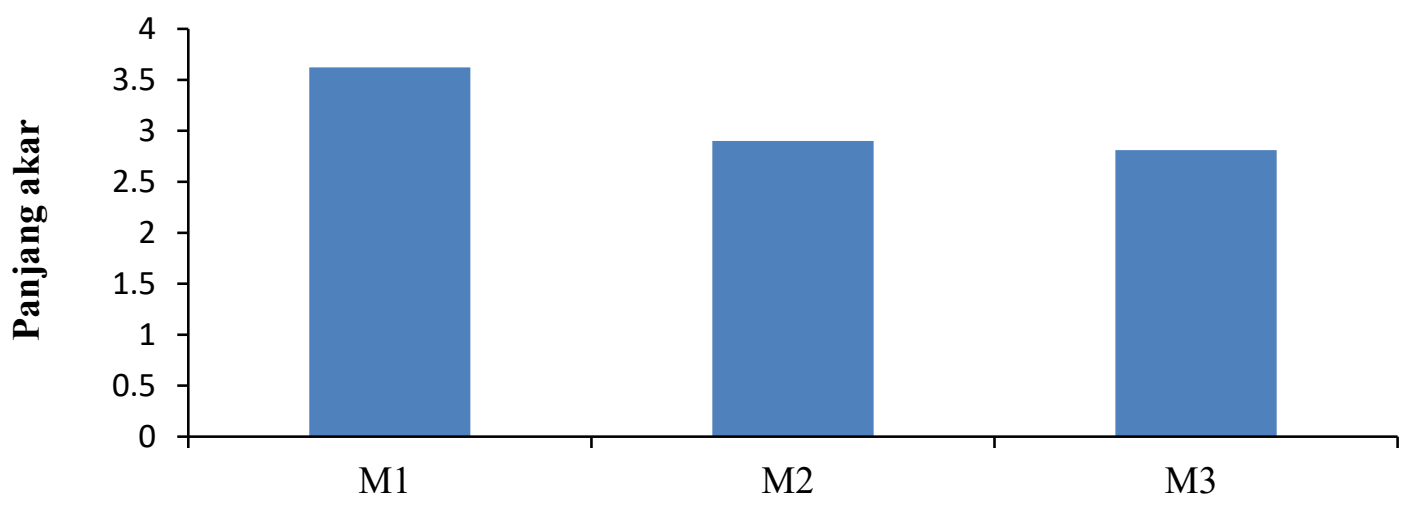

Gambar 5 Grafik Panjang Akar Faktor Tunggal Media

Hasil uji lanjut jenis media yang berpengaruh menunjukkan bahwa seluruh di seluruh parameter media yang terbaik ialah media cocopeat, kecuali pada parameter penambahan tinggi tanaman minggu ke-3 namun tidak berbeda nyata dengan perlakuan cocopeat. Hal ini sejalan dengan penelitian Adi et al. (2014) menyatakan bahwa persentase hidup, jumlah daun serta warna daun pada perlakuan media campuran arang dan serabut kelapa, moss dan pakis menunjukkan hasil terbaik. Persentase hidup tertinggi pada perlakuan kombinasi serabut kelapa dan arang pada pertumbuhan anggrek hitam yang dilaksanakan di Universitas Udayana, Bali. Media yang terbaik yaitu pada penggunaan media kombinasi media cocopeat dan ampas tebu pada tanaman anggrek dendrobium dengan optimal yang dilakukan penelitian di daerah Batu, Jawa Timur (Sucipto et al. 2019).

Hasil penelitian yang telah didapatkan menunjukkan bahwa meskipun berbeda jenis anggrek dan tempat daerah penelitian, perlakuan media cocopeat tanpa campuran mampu memperoleh hasil terbaik pada faktor tunggal media pada variabel persentase hidup, bobot basah, bobot kering, volume akar, volume akar serta kadar air.
Perlakuan media pakis menunjukkan hasil terbaik di parameter penambahan tinggi tanaman, namun tidak berbeda nyata dengan perlakuan media cocopeat.

Keberhasilan proses aklimatisasi dapat dilihat dari persentase hidup tanaman, perlakuan media cocopeat menunjukkan hasil tertinggi $64 \%$ dibanding dengan media pakis dan $52 \%$ lebih tinggi dibanding dengan media moss. Fungsi media ialah sebagai penyedia udara, penahan atau tempat penopang tanaman dan menjaga kelembaban di sekitar akar. Sabut kelapa yang memiliki kualitas baik yaitu yang memiliki warna coklat, bersih, bebas hama dan penyakit serta tanin dan berasa dari kelapa tua. Sifat media serabut kelapa yaitu mudah menyerap air, sebagai penyimpan air yang baik, mudah lapuk, mudah menjadi sumber penyakit atau jamur, mengandung tanin yang dapat merusak tanaman dan mudah didapat (Andiani, 2016). Serabut kelapa memiliki kandungan hara makro yaitu unsur K, $\mathrm{P}$ (Fosforus), N (Nitrogen), Ca (Kalsium), Mg (Magnesium) (Grimwood, 1975).

Kekurangan dari media cocopeat yaitu memiliki kandungan tanin. Tanin yang terkandung pada media dapat berpengaruh buruk pada tanaman yang ditandai dengan tanaman yang berwarna 
kemerahan. Upaya menghilangkan tanin pada awal penelitian ialah dengan cara merendam dan pencucian cocopeat selama 30 menit kemudian disaring, namun usaha tersebut masih belum efektif menghilangkan zat tanin tersebut.

Fungsi unsur hara didalam tanaman sebagai penyusun yang berbeda beda, unsure $\mathrm{K}$ berpengaruh dalam proses fotosintesis, translokasi karbohidrat, sintesis protein. Unsur fosforus sebagai penyusun banyak protein, fosfolipida, koenzim, asam-asam nukleat, dan koenzim. Unsur $\mathrm{N}$ sebagai penyusun asam-asam amino, protein, klorofil, asamasam nukleat, dan substrat. Unsur $\mathrm{Ca}$ sebagai komponen dinding sel, pertumbuhan dan pembelahan sel; kofaktor enzim, memainkan peranan dalam struktur dan permeabilitas membran sel. Unsur $\mathrm{Mg}$ sebagai komponen klorofil, sehingga esensial untuk sintesis makanan (Munawar, 2011).

Perlakuan cocopeat mendapat hasil yang terbaik karena telah memenuhi syarat dan fungsi media tanam yang dibutuhkan tanaman. Pakis hanya berpengaruh pada penambahan tinggi tanaman, namun tidak memberi pengaruh pada parameter lainnya. Pakis memiliki sifat menyerap air tinggi, masa pelapukan lama, sedikit unsur hara, aerasi dan drainase yang baik (Andiani, 2016). Pakis kurang cocok pada penelitian karena memiliki drainase yang baik, sedangkan lingkungan penelitian sangat ekstrem terlebih suhu yang tinggi. Teori tersebut selaras jika dilihat dari parameter bobot basah, bobot kering, dan kadar air yang memiliki nilai tertinggi dari perlakuan lain dengan ditandai oleh notasi yang berbeda.

Keberhasilan proses aklimatisasi ialah penutup keberhasilan pengembangbiakan secara kultur jaringan. Proses aklimatisasi sebagai masa kritis tanaman, karena masa penyesuaian dari lingkungan terkendali ke lingkungan yang tidak terkendali, dari faktor lingkungan hingga unsur hara yang dibutuhkan tanaman (Andiani, 2016). Keberhasilan proses aklimatisasi tidak jauh dari faktor lingkungan yang mempengaruhi tahap aklimatisasi, diantaranya suhu udara, kelembaban udara, dan intensitas cahaya. Suhu udara, tanaman ketika berada pada proses kultur jaringan mendapat suhu yang terkendali $\pm 25^{\circ} \mathrm{C}$, ketika pada tahap aklimatisasi suhu udara tidak dapat terkontrol (Zulkarnain, 2011). Usaha untuk membantu penyesuaian tanaman terhadap lingkungan in-vivo secara bertahap, tanaman disimpan pada tempat teduh yang tidak terpapar sinar matahari langsung selama 2 minggu.

Syarat tumbuh yang dikehendaki oleh anggrek vanda ialah $15-21^{\circ} \mathrm{C}$ sedangkan anggrek pada umumnya sekitar $15-28{ }^{\circ} \mathrm{C}$, namun yang diperoleh dari pengamatan suhu rata-rata selama penelitian ialah $30,3{ }^{\circ} \mathrm{C}$ suhu pagi hari (07.00-08.00), $35,8{ }^{\circ} \mathrm{C}$ suhu siang hari (12.00-13.00) dan $32,5^{\circ} \mathrm{C}$ suhu sore hari (16.00-17.00). Pengamatan pada tanggal 12 september hingga 10 oktober lingkungan penelitian suhu siang hari ialah suhu terparah yang memperoleh hasil mencapai $37-38{ }^{\circ} \mathrm{C}$. Oleh karena itu, lingkungan yang dilakukan penelitian tidak sesuai dengan syarat tumbuh tanaman.

Usaha yang dilakukan untuk menjaga persentase hidup tanaman ialah dengan melakukan penyiraman lantai penelitian pagi dan sore hari dan pemberian baki yang berisi air untuk mengurangi penguapan atau transpirasi. Intensitas cahaya juga sebagai faktor yang harus diperhatikan dalam tahap aklimatisasi, berkaitan erat dengan suhu dan kelembaban. Usaha yang dilakukan untuk menurunkan intensitas cahaya dengan penggunaan paranet sebagai 
naungan tanaman sehingga dapat mendukung keberhasilan tahap aklimatisasi.

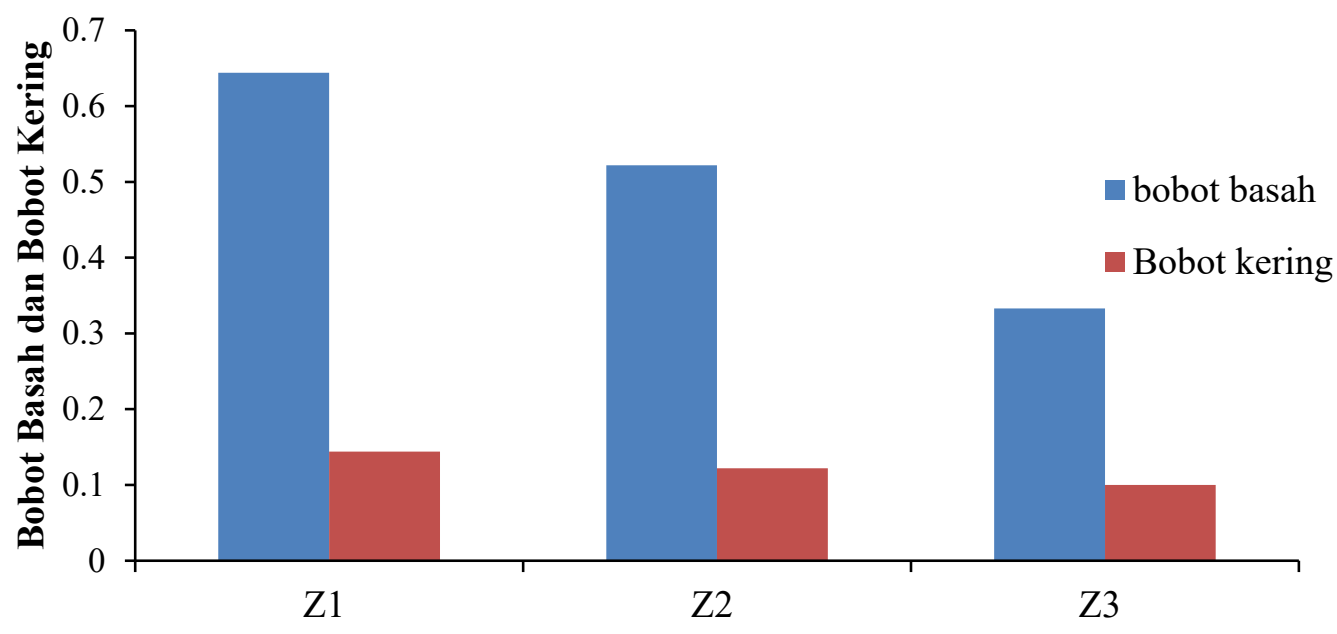

Gambar 6 Bobot Basah Dan Bobot Kering Faktor Tunggal ZPT

Hasil uji lanjut DMRT faktor tunggal jenis ZPT pada parameter bobot basah dengan nilai $F$ hitung 5.67 menunjukkan hasil analisis berbeda nyata, hasil terbaik pada perlakuan Z1 (bawang merah) namun tidak menunjukkan beda nyata pada Z2 (touge) (Tabel..3). Bawang merah dan tauge merupakan sumber ZPT auksin, oleh karena itu perlakuan bawang merah dan tauge menunjukkan hasil berbeda nyata. Hasil analisis menunjukkan bahwa parameter bobot basah perlakuan Z1 menunjukkan hasil tertinggi pada parameter bobot basah maupun bobot kering, dapat dilihat pada gambar 6.

Auksin merupakan
senyawa yang dapat mengatur

pertumbuhan tanaman yang khususnya merangsang perpanjangan sel pucuk. Sedangkan sitokinin ialah senyawa yang dapat meningkatkan serta merangsang pembelahan sel (Gardner et al. 1991). Dua zat pengatur tumbuh tersebut berpengaruh pada ujung pertumbuhan, namun pada umumnya perpanjangan sel bekerja pada masa vegetatife tanaman dan zat pengatur tumbuh sitokinin yang merangsang pembelahan sel pada umumnya lebih bekerja pada masa generatif tanaman. auksin tidak berpengaruh pada pembelahan sel namun sitokinin berpengaruh, pemanjangan batang berpengaruh oleh auksin namun tidak pada sitokinin (Gardner et al. 1991). 


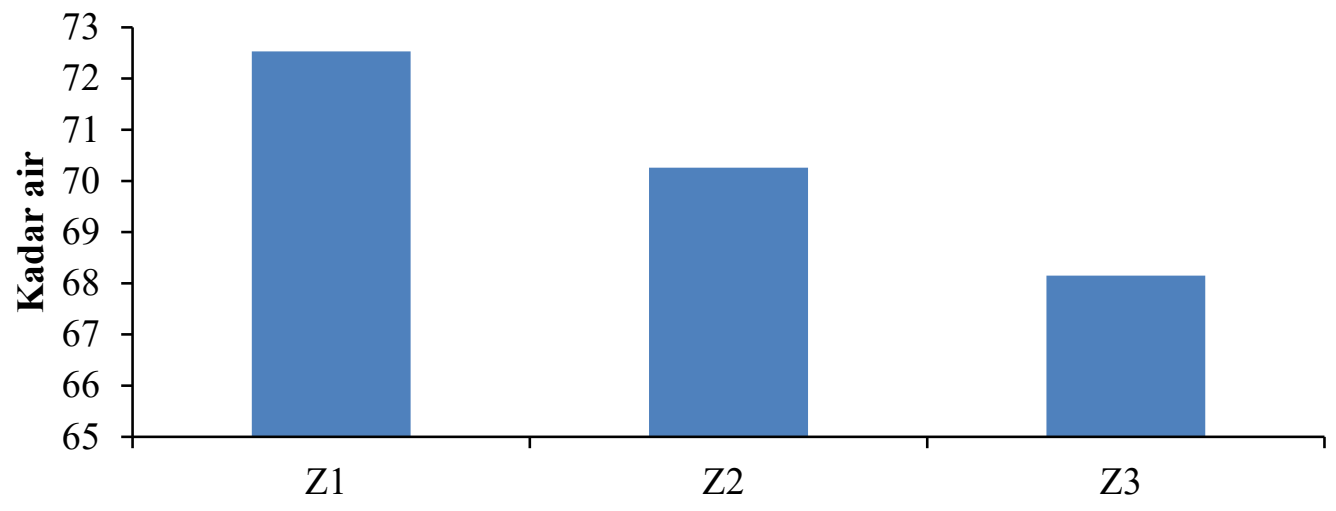

Gambar 7 Grafik Kadar Air Faktor Tunggal ZPT

Zat pengatur tumbuh auksin pada bawang merah dan tauge menunjukkan berpengaruh baik pada bobot basah dan bobot kering, hal tersebut selaras dengan kadar air tanaman meskipun tidak menunjukkan berbeda nyata tapi Z1 (bawang merah) menunjukkan hasil terbaik, dapat dilihat pada gambar 7

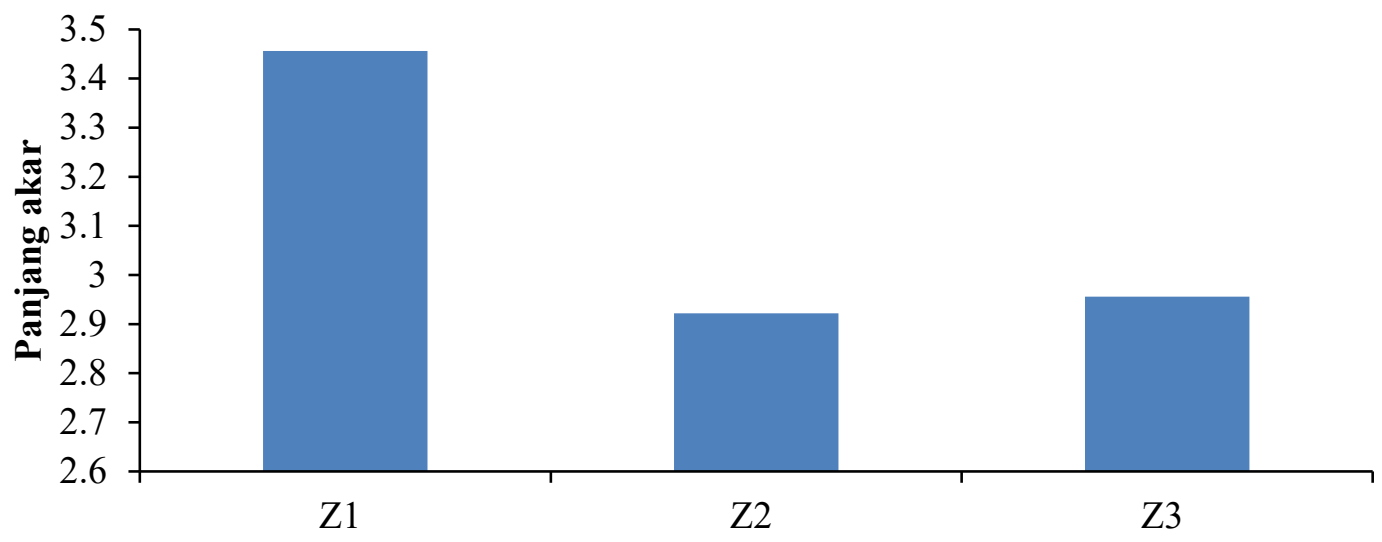

Gambar 8 Grafik Panjang Akar Faktor Tunggal ZPT

ZPT yang berpengaruh ialah pada $\mathrm{Z} 1$ namun tidak berbeda nyata dengan $\mathrm{Z} 2$ karena memiliki kandungan auksin, dapat disesuaikan dengan parameter panjang akar maupun volume akar. Panjang akar menunjukkan bahwa Z1 memiliki nilai tertinggi dari pada perlakuan lainnya dapat dilihat pada gambar 8 .

Volume akar menunjukkan hal yang sama, bahwa perlakuan bawang merah dan tauge menunjukkan hal yang sama baiknya, dapat dilihat pada gambar 9. ZPT tersebut berpengaruh pada perakaran tanaman, karena auksin dapat berpengaruh pada perpanjangan sel pucuk, selaras dengan parameter panjang akar dan volume akan. Auksin dan sitokinin sama-sama berpengaruh, namun auksin lebih bekerja pada masa vegetatif, sedangkan tanaman anggrek yang diaklimatisasi masih berada pada masa vegetatif 


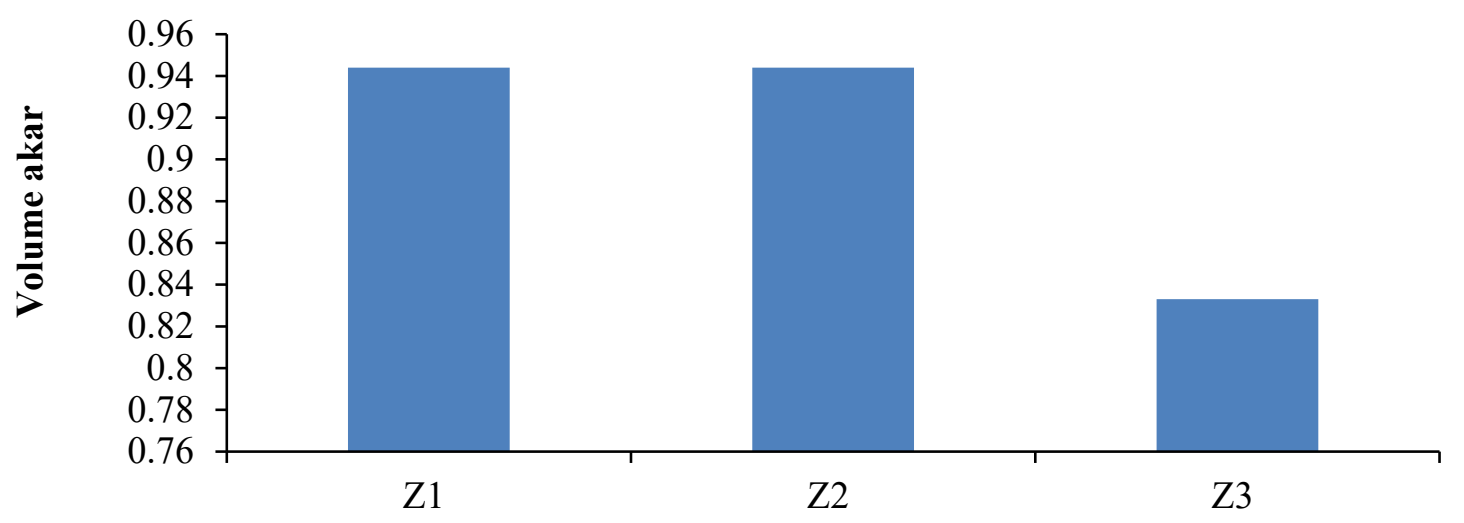

Gambar 9 Volume Akar Faktor Tunggal ZPT

Menurut Soffianingrum (2017) unsur hara dan ZPT merupakan hal yang lebih dibutuhkan pada pembentukan daun, daun yang terbuka tiap selnya akan melalui tiga fase dari pembelahan, pembesaran, hingga diferensiasi. Daun sebenarnya terbentuk setelah proses aklimatisasi 3 bulan setelah tanam, oleh karena itu, bibit anggrek yang berumur 3 bulan belum mampu membentuk daun yang maksimal. Parameter penambahan yang telah diamati tidak menunjukkan hasil analisis berbeda nyata, salah satu faktor penyebab ialah bibit anggrek vanda belum membentuk organ secara maksimal, meskipun telah dibantu dengan pengapikasian berbagai jenis zat pengatur tumbuh alami dan hormon tanaman itu sendiri namun pengaruh pemberian ZPT dapat dilihat pada parameter bobot basah dan bobot kering yang menandakan hasil laju pertumbuhan vegetatif tanaman dan bobot kering menandakan hasil fotosintesis tanaman.

Pengaruh ZPT yang berkerja untuk pemanjangan sel pucuk dapat dilihat pada ujung akar di parameter panjang akar dan volume akar yang menunjukkan auksin yang terkandung pada bawang mera dan tauge berkerja, ditandai dengan nilai tertinggi, namun jika dilihat di pucuk daun masih tidak menunjukkan berbeda nyata karena belum tumbuh secara maksimal.

Tabel 4 Hasil uji DMRT penambahan diameter batang minggu ke-9

\begin{tabular}{cllllll}
\hline \multirow{2}{*}{ Jenis Media } & \multicolumn{9}{c}{ Jenis ZPT } \\
\cline { 2 - 7 } & \multicolumn{2}{c}{ Z1 } & \multicolumn{2}{c}{ Z2 } & \multicolumn{2}{c}{ Z3 } \\
\hline M1 & 0.008 & $\mathrm{a} \mathrm{A}(\mathrm{a})$ & 0.006 & $\mathrm{aA}(\mathrm{ab})$ & 0.001 & $\mathrm{bB}(\mathrm{ab})$ \\
M2 & 0.002 & $\mathrm{ab} \mathrm{B}(\mathrm{ab})$ & 0.000 & $\mathrm{bB}(\mathrm{b})$ & 0.006 & $\mathrm{aA}(\mathrm{ab})$ \\
M3 & 0.001 & $\mathrm{~b} \mathrm{~A}(\mathrm{ab})$ & 0.001 & $\mathrm{bA}(\mathrm{ab})$ & 0.002 & $\mathrm{bA}(\mathrm{ab})$ \\
\hline
\end{tabular}

Keterangan: M1: Media cocopeat, M2: Media pakis, M3; Media moss, Z1: Ekstrak bawang merah, Z2: Ekstrak tauge, Z3: Air kelapa. Angka yang diikuti dengan huruf kecil yang sama pada kolom yang sama tidak berbeda nyata pada uji DMRT taraf 5\%. Angka diikuti huruf kapital yang sama pada baris yang sama tidak berbeda nyata pada uji DMRT taraf 5\%. Angka yang diikuti oleh huruf kecil dalam tanda kurung yang sama menunjukkan tidak berbeda nyata pada uji DMRT 5\%

Hasil analisis uji lanjut DMRT 5\% dua arah interaksi jenis media dan jenis ZPT parameter penambahan diameter batang minggu ke-9 dapat dibaca pada Tabel 5 Hasil uji DMRT bobot basah tabel (Tabel 4). Hasil terbaik pada perlakuan M1Z1 (cocopeat dan bawang merah). 


\begin{tabular}{ccccccc}
\hline \multirow{2}{*}{ Jenis Media } & \multicolumn{7}{c}{ Jenis ZPT } \\
\cline { 2 - 7 } & \multicolumn{7}{c}{ Z1 } & \multicolumn{2}{c}{ Z2 } & Z3 \\
\hline M1 & 1.100 & $\mathrm{aA}(\mathrm{a})$ & 0.967 & $\mathrm{aA}(\mathrm{ab})$ & 0.400 & $\mathrm{aB}(\mathrm{b})$ \\
M2 & 0.333 & $\mathrm{bA}(\mathrm{b})$ & 0.333 & $\mathrm{bA}(\mathrm{b})$ & 0.333 & $\mathrm{aA}(\mathrm{b})$ \\
M3 & 0.500 & $\mathrm{bA}(\mathrm{b})$ & 0.267 & $\mathrm{bA}(\mathrm{b})$ & 0.267 & $\mathrm{aA}(\mathrm{b})$ \\
\hline
\end{tabular}

Keterangan: M1: Media cocopeat, M2: Media pakis, M3; Media moss, Z1: Ekstrak bawang merah, Z2: Ekstrak tauge, Z3: Air kelapa. Angka yang diikuti dengan huruf kecil yang sama pada kolom yang sama tidak berbeda nyata pada uji DMRT taraf 5\%. Angka yang diikuti huruf kapital yang sama pada baris yang sama tidak berbeda nyata pada uji DMRT taraf 5\%. Angka yang diikuti oleh huruf kecil dalam tanda kurung yang sama menunjukkan tidak berbeda nyata pada uji DMRT $5 \%$.

Hasil analisis uji lanjut DMRT 5\% dua arah interaksi jenis media dan jenis ZPT pada parameter bobot basah dapat dibaca dibawah ini (Tabel 4.5). Hasil terbaik pada perlakuan M1Z1 (cocopeat Hasil analisis interaksi menunjukkan bahwa M1Z1 menunjukkan hasil terbaik di parameter penambahan diameter, hal tersebut menunjukkan bahwa media M1 dan Z1 berpengaruh. Media yang terbaik ialah M1 (cocopeat) pada analisis faktor tunggal media dan Z1 (bawang merah) pada analisis faktor tunggal ZPT. Hasil analisis yang ke-2 pada parameter bobot basah menunjukkan hasil terbaik pada M1Z1 dan tidak berbeda nyata dengan M1Z2.

Media cocopeat memiliki kandungan mineral unsur $\mathrm{K}, \mathrm{P}, \mathrm{N}, \mathrm{Ca}$, serta $\mathrm{Mg}$ dengan sifat mudah menyerap air, menyimpan air yang baik. Zat pengatur tumbuh bawang merah dan tauge yang memiliki kandungan yang hampir sama yaitu hormone auksin ternyata menunjukkan saling berpengaruh dengan media cocopeat. Media cocopeat yang memiliki sifat mudah menyerap air dan dapat menyimpan air dengan baik merupakan hal yang dapat membantu penyimpanan ZPT yang diberikan serta memudahkan tanaman dalam penyerapan ZPT yang diberikan dalam bentuk cair.

\section{KESIMPULAN}

dan bawang merah) namun tidak berbeda nyata pada parameter M1Z2, karena notasi yang diperoleh masih diikuti huruf yang sama.

Respon tanaman terhadap aplikasi penggunaan jenis media dan jenis ZPT terhadap keberhasilan proses aklimatisasi dan pertumbuhan anggrek berdasar variabel pengamatan yang diamati menunjukkan bahwa,

1. Media cocopeat (M1) menunjukkan hasil cenderung terbaik pada parameter persentase hidup, penambahan tinggi tanaman minggu ke-3, bobot basah, bobot kering, kadar air dan volume akar.

2. Faktor tunggal jenis ZPT bawang merah (Z1) menunjukkan hasil cenderung baik hanya pada parameter bobot basah.

3. Media cocopeat dan ZPT bawang merah (M1Z1) menunjukkan hasil berpengaruh nyata pada parameter penambahan diameter batang minggu ke-9 dan bobot basah

\section{DAFTAR PUSTAKA}

Adi, N. K., Astarini, I. A., \& Astiti, N. P. (2014). Aklimatisasi Anggrek Hitam (Coelogyne pandurata Lindl) hasil perbanyakan In-Vitro pada Media Berbeda. Jurnal Simbiosis , II (2), 01-12. 
Alimudin, Syamsiah, M., \& Ramli. (2017). Aplikasi Pemberian Ekstrak Bawang Merah (Allium cepa L.) Terhadap Pertumbuhan Akar Stek Batang Bawah Mawar (Rosa Sp.) Varietas Malltic. Jurnal Agroscience, VII (01), 194-202.

Andarini, Y. N. (2013). Respon Planlet Anggrek Dendrobium spectabile pada Pemberian Beberapa Taraf Paclobutrazol Selama Tahap Aklimatisasi. Skripsi. Fakultas Pertanian, Institut Pertanian Bogor, Bogor.

Andiani, Y. (2016). Usaha Pembibitan Anggrek Dalam Botol Tehnik In Vitro. Yogyakarta: Pustaka Baru Press.

Badan Pusat Statistik. (n.d.). Data Ketinggian Wilayah Diatas Permukaan Laut (DPL) Menurut Kecamatan di Kabupaten Lamongan. Retrieved Mei 05, 2021, from Badan Pusat Statistik: https://lamongankab.bps.go.id/stat ictable/2018/02/07/747/ketinggian -wilayah-diatas-permukaan-lautdpl-menurut-kecamatan-dikabupaten-lamongan-2016.html

Badan Pusat Statistik. (2018). Data Statistik Produksi Tanaman Hias Indonesia di Jawa Timur tahun 2018. Retrieved Juni 04, 2020, from Badan Pusat Statistik: http://.bps.go .id

Dwiyani, R. (2014). Anggrek Vanda Tricolor Lindl Var Suavis. Bali: Udayana University Press.

Gardner, F. P., Pearce, R. B., \& Mitchell, R. L. (1991). Fisiologi Tanaman Budidaya. Jakarta: UI Press.

Grimwood, B. E. (1979). Coconut Palm Products. Italy: FAO.

Hariyanto, S., Jamil, A. R., \& Purnobasuki, H. (2019). Effects of
Plant And Fertilization on The Growth of Orchid Plant (Dendrobium sylvanum rchb. F.) in Acclimatization Phase. Jurnal Agrosains , VII (1), 66-72.

Kurniati, F., Sudartini, T., \& Hidayat, D. (2017). Aplikasi Berbagai Bahan ZPT Alami Untuk Meningkatkan Pertumbuhan Bibit Kemiri Sunan (Reutealis trisperma (Blanco) Airy Shaw. Jurnal Agro , IV (01), 40-49.

Marfirani, M., Rahayu, Y. S., \& Ratnasari, E. (2014). Pengaruh Pemberian Berbagai Konsentrasi Filtrat Umbi Bawang Merah dan Rootone-F Terhadap Pertumbuhan Stek Melati "Rato Ebu" . Jurna LenteraBio , III (01), 73-76.

Mariana, M. (2017). Pengaruh Media Tanam Terhadap Pertumbuhan Stek Batang Nilam (Pogostemon cablin Benth) . Jurnal Agrica Ekstensi , XI (01), 1-8.

Munawar, A. (2011). Kesuburan Tanah Dan Nutrisi Tanaman. Bogor: IPB Press.

Nikmah, Z. C., Slamet, W., \& Kristanto, B. A. (2017). Aplikasi Silika dan NAA Terhadap Pertumbuhan Anggrek Bulan (Phalaenopsis amabilis I.) Pada Tahap Aklimatisasi. Jurnal Agro Complex , I (03), 101-110.

Pangesti, R., \& Sulistyowati. (2015). Pengaruh Peberian Air Tauge dan Air Kelapa Terhadap Pertumbuhan Tunas Nilam (Pogestemon cablin Benth) Secara In Vitro. Jurnal Stigma , VIII (01), 21-24.

Ramli, \& Alimudin, M. (2016). Pengaruh Konsentrasi Ekstrak Bawang Merah (Allium cepa L.) Terhadap Pertumbuhan Akar Stek Batang 
Bawah Mawar (Rosa Sp). Jurnal Agroscience, VI (02), 70-77.

Saputri, W., Mukarlina, \& Linda, R. (2015). Respon Pertumbuhan Anggrek Hitam (Coelogyne pandurata Lindl.) Secara In-Vitro dengan Penambahan Ekstrak Tauge dan Benzyl Amino Purin (BAP). Jurnal Protobiont , IV (2), 84-89.

Soffianingrum, R. M. (2017). Pengaruh jenis Media Tanam dan Pupuk Daun Terhadap Pertumbuhan Vegetatif Anggrek Vanda sp. Pada Tahap Aklimatisasi. Skripsi. Fakultas Keguruan dan Ilmu Pendidikan, Universitas Nusantara PGRI Kediri, Kediri.
Widyastoety, D., \& Santi, A. (2012). Keunggulan Kelompok Anggrek Vanda Dalam Meningkatkan Variasi dan Kualitas Anggrek Bunga Potong. Prosiding Seminar Nasional Anggrek (pp. 117-128). Cianjur: Balai Penelitian Tanaman Hias.

Yasmin, Z. F., Aisyah, S. I., \& Sukma, D. (2018). Pembibitan (Kultur Jaringan hingga Pembesaran) Anggrek Phalaenopsis di Hasanudin Orchids, Jawa Timur. Jurnal Agrohorti , VI (03), 430439.

Zulkarnain. (2011). Kultur Jaringan Tanaman Solusi Perbanyakan Tanaman Budi Daya. Jakarta: Bumi Aksara. 